DOI https://doi.org/10.18551/rjoas.2017-11.28

\title{
EFFECT OF ENTREPRENEURIAL COMPETENCY ON COMPETITIVE ADVANTAGE AND MARKETING PERFORMANCE IN MICRO, SMALL AND MEDIUM ENTERPRISES OF SEAWEED PROCESSING
}

\author{
Abdullah Akmal \\ Department of Agribusiness, Pangkep State Polytechnic of Agriculture, Indonesia \\ E-mail: akmalabdullah23@gmail.com
}

\begin{abstract}
Indonesia has a very abundant seaweed resource and is a major producer of world seaweed. However, Indonesia still sells more seaweed without being processed. It is only dried seaweed which has very low value compared to when it is processed. This study aims to examine and analyze the effect of entrepreneurial competency on competitive advantage and marketing performance on Micro, Small, and Medium Enterprises (MSME) processing seaweed in South Sulawesi Province. Population in this research is all owner/manager at Micro, Small, and Medium Enterprises (MSME) of seaweed processing in South Sulawesi Province fulfilling criteria according to Law Number 20 Year 2008 regarding Micro, Small, and Medium Enterprises (MSME). Owners/managers are selected because they know best the strategies implemented by MSMEs. The total samples of this study are 158 respondents. Besides, the analysis method used Structural Equation Model (SEM) by utilizing AMOS and SPSS program. The results of the study find that entrepreneurial competency positively and significantly gives effect on competitive advantage. The better the entrepreneurial competency of an entrepreneur, the more increasing the competitive advantage will be. Entrepreneurial competency has a direct positive and insignificant influence on marketing performance. It is because the reliable entrepreneurial competency that an entrepreneur possesses will drive to increase marketing performance.
\end{abstract}

\section{KEY WORDS}

Competitive advantage, entrepreneurial competency, marketing performance.

Indonesia's marine wealth has not been fully utilized in the right way so that it affects the national economy. It is confirmed that Indonesia has an area of $6.315 .222 \mathrm{~km} 2$ of waters with 99,093 kilometers of coastline as well as the number of islands of 13,466 islands. Indonesia has a very abundant seaweed resource and is a major producer of world seaweed. Seaweed is one of the country's sources of foreign exchange and a source of income for coastal communities. There are 500 high value products that can be produced from seaweed. However, Indonesia still sells more seaweed without being processed. It is only dried seaweed which has very low value compared to when it is processed. Seaweed is very potential to be a superior commodity of Indonesia. When it is processed correctly, potency of seaweed can reach hundreds of billion rupiah. Seaweed is a high class product whose customers are from all over the world. In addition to being used as food, beverages and medicines, some processed seaweed such as gelatin, alginate, and carrageenan are quite important compounds in the industry.

Micro, Small and Medium Enterprises (MSMEs) have an important role as the backbone of the economy in almost all countries. In Indonesia, MSMEs contribute significantly to the Gross Domestic Product (GDP), which is $60 \%$ with total employment reach to $97 \%$ of total workforce (BPS, 2011).

South Sulawesi province is recorded as the largest producer of seaweed in Indonesia with a potential land of 250 thousand hectares on the seafront and 98 thousand hectares of cultivation area. From that area, South Sulawesi generates about 25 thousand tons per year. South Sulawesi is the second largest sea-producing region in the world after Chile which is capable of producing about 50 thousand tons per year. 
The company's strategy is always directed to produce good marketing performance (such as sales volume and sales growth rate) as well as good financial performance. High marketing performance is expressed in three major values, namely sales value, sales growth, and market share (Ferdinand, 2000).

Entrepreneurial competency is a representation of the managerial capacity to explain the relationship between the attributes and the behavior of the owner/manager of the business success (Bird, 1995; Man.et al., 2002). Ahmad et al. (2010) defines entrepreneurial competency as an individual characteristic that includes attitudes and behaviors that trigger entrepreneurs to achieve and maintain business success or performance. Moreover, business performance is determined from the relationship between attributes and behaviors through the ability of owner/manager behave in running their business and behavior aspect is the representation of entrepreneur to execute strategy in entrepreneurship.

The most important thing in achieving the success of the strategy implemented is to identify the true company assets, in this case the tangible and intangible resources that make the organization unique (Porter and Van der Linde, 1995). There are two footholds in achieving competitive advantage which are resource superiority and position superiority, meaning that the company's competitive advantage is affected by performance (Day and Wensley, 1988). RBV is expressed as a strategic approach with two different views, namely the tendency of views that lead to capabilities that are the core of competition but are still influenced by market forces (Barney, 1991). RBV indirectly recommends to companies (MSMEs) to focus on more efficient resource utilization. Management business based on resources (Resources-based) is one of the alternative solutions for MSMEs because through such management, it is able to create a special competence and to provide strategic selection for reach sustainable competitive advantage (Barney, 1991). For gaining sustainable competitive advantage, it is not free from resource based-view (RBV) that directs companies' management to identify, master, and develop strategic resources in order to make optimal performance (Barney et al., 2007).

Based on the results of empirical review, this research is conducted by purposes to test and to explain how the effect of market orientation and entrepreneurial competency towards MSMEs competitive advantage and marketing performance of seaweed processing in South Sulawesi Province.

\section{LITERATURE REVIEW}

Theory of Resource-Based View of the Firm (RBV Theory). Some views in outlining and classifying resources within the company are provided. Company resources can include: all assets, capabilities, organizational processes, company attributes, information, knowledge, and others that are controlled by the company and it enables the company to formulate and implement strategies that will improve its efficiency and effectiveness.

The RBV theory is usually expressed as a strategic approach with two different views, namely the tendency to view that leads to capabilities that are the core of competitive position but are still influenced by market forces (Barney, 1991). RBV indirectly advises companies to focus on the more efficient use of resources.

Resources refer to tangible assets, where resources can be financial and physical assets, licenses and patents, trademarks, reputation, skills as trade secret, scientific processes and knowledge and social capital and human capital, including networks, organizational culture, and collective learning (Ainuddin et al., 2007).

Based on the view of the resources grouping, it can be seen that basically the company's resources can be in the form of tangible assets, the physical and financial resources used by the company to provide value for customers. These assets include: production facilities, raw materials, financial resources, buildings and equipment. These resources are easily identifiable and are often included in a company's balance sheet. Resources are also in the form of intangible assets, a power source such as brand, corporate reputation, organizational morale, technique understanding, patents and trademarks, as well as the accumulated experience of the organization. Lastly, the company's resources are 
organizational capabilities, which are not specific inputs such as intangible assets, but it is rather capabilities and ways to combine the assets, labor, and processes that an organization uses to convert inputs into outputs.

Entrepreneurial Competency. Success or failure of effort will be affected by the skills and abilities (competencies) of the owner/manager. Understanding the role of entrepreneurs provides a better insight into what competencies are required by employers to ensure business survival and business success (Akhmad et al., 2010: 67-75). Kiggundu (2002: 239) states that entrepreneurial competence is as a whole of entrepreneur attributes such as attitudes, beliefs, knowledge, skills, abilities, personalities, competencies, and behavioral trends which are necessary to maintain and to succeed business. Successful entrepreneurs are entrepreneurs who have the competence that is: someone who has the knowledge, skills, and individual qualities that include the attitudes, motivations, values, and behaviors which are necessary to perform the work or activities.

Entrepreneurial competency is an important factor in advancing the business. The dominant contributors to business success cover: personality traits (49\%), ability to connect with customers $(17 \%)$, ability to understand the business environment $(15 \%)$, future orientation and flexibility (11\%), personal awareness (4\%), and other factors (4\%) (Hasan, 2015). Success or failure of effort will be affected by skills and abilities (competencies) of the owner or manager. Understanding the role of entrepreneurs provides a better insight into what competencies are required by employers to ensure business survival and business success.

Competitive advantage. Basically, every company that competes in an industrial environment has a desire to be superior to its competitors. Generally, company applies this competitive strategy explicitly through the activities of various existing company functional departments. The basic idea of creating a competitive strategy begins with the development of a general formula of how business will be developed, what exactly the goal is, and what policy will be needed to achieve that goal.

The definition of competitive advantage itself has two different meanings but it is interconnected. The first definition emphasizes superiority in terms of resources and expertise of the company. Companies that have competence in marketing, manufacturing, and innovation can make it as a source to achieve competitive advantage. Through these three areas of competence, the company can develop strategies so that it can produce products that sell well in the market. On the other hand, the second definition emphasizes the superiority in achievement of performance over the years.

The term competitive advantage according to Day and Wensley (1988: 5) has at least two different but it has related meanings that competitive advantage can be defined as focusing on excellence (superiority) in skill or resources, while the second is related to competitive advantage of performance results.

Marketing Performance. Marketing performance is a common construction (factor) used to measure the impact of the company's strategy. Company's strategy is always directed to produce performance, both marketing performance and financial performance. Marketing performance is a concept to measure the market performance of a product (Ferdinand, 2000).

Barney (1991) states that firms can have competitive performance if: (1) they know how to extend, disseminate, and exploit knowledge internally; (2) if they know how to protect knowledge from competitors' imitations; (3) if they know how to share (share / transfer) and receive knowledge from their business partners. Therefore, it can be concluded that the main role of the next company or organization is to manage the asset knowledge in order to improve its performance.

Performance refers to the level of achievement of the company within a certain period of time. The company's performance is crucial in the development of the company. The purpose of the company to remain exist, gain profit, and can grow (growth) can be achieved if the company has a good performance. Performance of the company can be seen from the level of sales, profit, the rate of capital return, the level of turnover, and market share which are achieved (Jauch and Glueck, 1998). 
Based on the phenomenon, theoretical and empirical studies presented above, Grand Theoretical Model or Basic Theoretical Model can be described which is the basis of this research, as in the following figure:

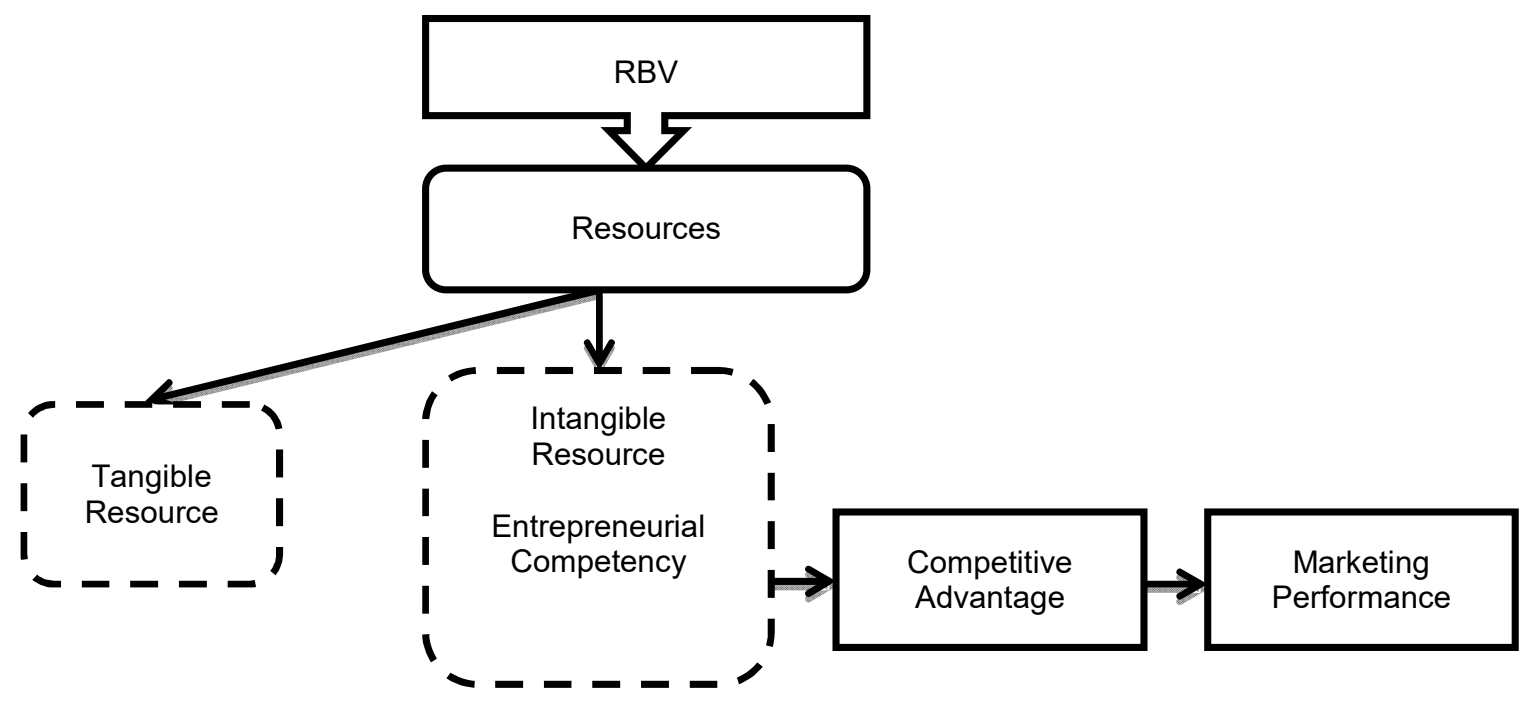

Figure 1 - Theoretical Framework Research

(Source: Processed from the study of concepts and previous studies, 2016)

\section{METHODS OF RESEARCH}

This research is an exploratory research that is trying to find relationships that are relatively new, and explanatory research is done by describing the symptoms caused by a research object. Sources of data in this study consist of primary and secondary data. Primary data is the data obtained from observation, questionnaire, and interview. Besides, secondary data is the data obtained from MSMEs' document of seaweed processing in South Sulawesi. The unit of analysis is all owners and managers of MSMEs of seaweed processing in South Sulawesi. The sample is determined by using Probability sampling method. The owner and manager selection as the unit of analysis is caused because they (owner/manager) are the main resource owned by MSMEs. Besides, the owner and manager are individuals who are considered being able to explain the variables analyzed. The total samples of this study are 158 respondents. Data analysis techniques used in explaining the phenomenon in this research is descriptive statistical analysis techniques and analysis of Structural Equation Modeling (SEM). Calculations in descriptive statistical analysis are performed with the help of computers using the AMOS program and SPSS version 22.0.

\section{RESULTS OF STUDY}

The results of research and discussion in this study focus on the problems observed that will be analyzed in accordance with the results of data if using statistics after the data tabulated and validated in normality and reliability. Furthermore, the frequency is done to analyze the characteristics of respondents and each variable according to the indicator, then SEM analysis (Structural Equation Model) is conducted to see the variable constructs in accordance with the eight criteria of goodness of fit to test the hypothesis in knowing direct effect and indirect effect whether it is positive or negative and significant or not significant.

The analysis of the research result is by using Structural Equation Model (SEM) model with confirmatory factor analysis (CFA) of AMOS 24.0 Program (Analysis of Moment Structure, Arbukle, 1997). The predictive power of the observed variables at both individual and construction levels is seen through the critical ratio (CR). If the critical ratio is significant, then the dimensions will be stated useful for predicting constructs or latent variables. The latent variable(construct) of this research consists of entrepreneurial competency, 
competitive advantage, and marketing performance. By using the structural equation model of AMOS, dimensions of fit model will be obtained. The benchmark used in testing each hypothesis is the value of the critical ratio $(C R)$ in the regression weight with a minimum value of 2.0 in absolute terms.

The criterion used is to test whether the proposed model is compatible with the data or not. The fit model criterion consists of: 1) The degree of freedom must be positive and 2) Significance of Chi-square (for sample $\leq 250)$ required ( $p \leq 0.05$ ). Hair et al. (2006: 753), 3) incremental fit above 0.90 ie GFI (goodness of fit index), Adjusted GFI (AGFI), Tucker Lewis Index (TLI), The Minimum Sample Discrepancy Function (CMIN) divided by degree of freedom (DF) and Comparative Fit Index (CFI), and 4) RMSEA (Root Mean Square Error of Approximation) is low.

From the evaluation model, it shows that the eight criteria of goodness of fit index are seen from the eight criteria proposed, although none has met the criteria, but look at the number of samples and indicators in this study, then there needs to be a proof whether there is a suitability between the model and the data through the fulfillment of goodness of fit index criteria until modification of the model by performing correlation between error indicators in accordance with the instructions of modification indix with modification requirements are made without changing the meaning of relationships between variables.

The test result of model conformity gives $P$-Value of Chi-square statistics on degree of freedom does not meet the fit model criterion $(P \leq 0.05)$. However, if seen from other GFT, both RMSEA and CFI values meet the fit model criteria (RMSEA $0.040 \leq 0.08$ and CFI 0.969 $\geq 0.95$ ). Hence, it can be concluded that the proposed model fit with the data. It means that the proposed model is able to estimate the population kofarian matrix which is not different from the sample data covariance matrix. It suggests that the model parameter estimation results can be applied to the population. Hair (2006) in Kusnendi (2008: 341)

Based on the empirical model proposed in this study, the hypothesis proposed through the testing of path coefficients in the model of structural equations can be tested. The following table is a hypothesis testing by looking at the value of $p$ value, if the value of $p$ value is smaller than 0.05 , then the relationship between the variables is significant. Test results are presented in the following table:

Table 1 - Direct Effect Hypothesis Testing

\begin{tabular}{|c|c|c|c|c|c|c|}
\hline HIP & $\begin{array}{c}\text { Independent } \\
\text { Variables }\end{array}$ & \multirow{2}{*}{$\begin{array}{c}\text { Dependent } \\
\text { Variables }\end{array}$} & Coefficient & CR & $\begin{array}{c}p- \\
\text { value }\end{array}$ & Information \\
\hline H1 & $\begin{array}{c}\text { Entrepreneurial } \\
\text { Competency }\end{array}$ & $\begin{array}{c}\text { Competitive } \\
\text { Advantages }\end{array}$ & 0,266 & 2,005 & 0,045 & $(+)$ Significant \\
\hline H2 & $\begin{array}{c}\text { Entrepreneurial } \\
\text { Competency }\end{array}$ & Marketing Performance & 0,105 & 0,746 & 0,455 & $\begin{array}{c}(+) \text { Not } \\
\text { Significant }\end{array}$ \\
\hline
\end{tabular}

From the two hypothesized direct path models, there is one significant path and one insignificant path.

\section{DISCUSSION OF RESULTS}

$H_{1}$. The Effect of Entrepreneurial Competency to Competitive Advantage on MSMEs of Seaweed Processing. Entrepreneurial competency has a significant positive effect on the performance of competitive advantage with $P=0.045<0.05$ with a coefficient of 0.226 indicates that the better the entrepreneurial competency of an entrepreneur, the more increasing the competitive advantage will be.

Based on the results of research, it proves that directly entrepreneurial competency has a positive and significant impact on competitive advantage in MSMEs of seaweed processing. It reveals that entrepreneurial competency is already owned and provides an increase to the competitive advantage of MSMEs processing seaweed. The higher the competence of entrepreneurship, the more increasing the competitive advantage will be. 
The dimension of building the concept of the highest respondent appraisal is the part of the entrepreneurial competency possessed by every business actors of MSMEs in processing seaweed product to realize competitive advantage. Building on the concept means that the ability of business actors to develop their new business ideas into something real actualized in developing a business oriented to increasing competitiveness. Building a business concept becomes an important and essential thing for business actors to determine and to take strategic decisions in realizing competitive advantage that it faces according to the uniqueness of the product, the quality of the offered product, and the price competition.

The dimension of taking advantage of opportunities is the part of the entrepreneurial competency that is destined for business actors to have a careful instinct in viewing various opportunities and exploit these opportunities concretely to gain recognition and development to realize competitive advantage. Utilizing the opportunity is the principal for every business actor such as MSME to always search, determine, and exploit the opportunities available to be able to develop seaweed product business by continuously expanding the development in realizing competitive advantage based on the uniqueness of the product, the quality of the offered product, and the price competition.

The dimension of building relationships that according to the assessment of the respondents is still weak is the part of the entrepreneurial competency that should be owned by business actors such as MSMEs in finding various relationships to be invited to cooperate in developing and expanding the partnership network to support the strengthening of business actors to be able to have competitive advantage. Building relationships means creating partnerships with other business actors working in the same field to develop and to promote business in order to become a competitive business leader to introduce the uniqueness of its products, to guarantee product quality, and to develop a competitive pricing policy.

The dimension of learning is the part of the entrepreneurial competency that must be had by every business actor to always look for various learning resources, then participate in the learning process, able to evaluate the achievement of a learning that has been occupied by business actors, which causes the business actor able to realize competitive advantage. The learning process of entrepreneurs in the field of entrepreneurship requires that business actors have experience, follow the existing development of skills from the training that followed, in order to lead and able to develop their business in accordance with the competitive advantage that must be actualized. The form of learning process that requires business actors able to create work standards in order to have competitive advantage by constantly developing product uniqueness, product quality and competitive pricing in the process of trying as in the field of MSMEs of seaweed processing.

The dimension of personal ability is the part of the entrepreneurial competency in which every business actor is required to have a host to never give up in running the business, the knowledge of identifying opportunities and threats, strengths and weaknesses, as well as the ability to motivate themselves and others so that with the provision of these personal capabilities, business actors, such as MSMEs, are able to increase the competitive advantage with the same business actors. On this basis, it is necessary to continuously improve and enhance the ability of business actors that will be developed into a professional capability in the business field in order to increase competitive advantage.

Entrepreneurial competency is a capability had by business actors in running their business in accordance with their potential. The competence of business actors of MSMEs is seen from their ability to build concepts, take advantage of opportunities, build relationships, have potential learning, and have personal skills in striving to realize competitive advantage.

The reason for entrepreneurial competency has a positive and significant impact on competitive advantage because the success of MSMEs is determined by the ability of business actors in expanding their potential in concept, opportunity, customer relationship, learning activity, and personality ability shown to be very supportive for business actors to enhance competitive advantage in creating unique product ideas and concepts to market, able to exploit opportunities according to ability, cost and maintain good relationships with all 
parties in business, and also have the advantage to maintain competitive prices among business actors of MSMEs engaged in the same field.

$\mathrm{H}_{2}$. The Effect of Competence on Marketing Performance in MSMEs of Seaweed Processing. Entrepreneurial competency has an insignificant positive effect on marketing performance with $\mathrm{P}=0.455>0.05$ with coefficient value of 0.105 , indicating that entrepreneurial competency owned by an entrepreneur has not been able to improve marketing performance. It shows that entrepreneurial competency had by an entrepreneur encourages to increase competitive advantage thereby it impacts on the increase of marketing performance.

Based on the results of research, it is proven that directly entrepreneurial competency has a positive and significant impact on competitive advantage in MSMEs of seaweed processing. It shows that entrepreneurial competency is already owned and provides an increase to the competitive advantage of MSMEs processing seaweed. The higher the competence of entrepreneurship, the more increasing competitive advantage will be.

The dimension of building the concept of the highest respondent appraisal is the part of the entrepreneurial competency possessed by every business actors of MSMEs in processing seaweed product to realize competitive advantage. Building on the concept means that the ability of business actors to develop their new business ideas into something real actualized in developing a business oriented to increasing competitiveness. Building a business concept becomes an important and essential thing for business actors to determine and to take strategic decisions in realizing competitive advantage that it faces according to the uniqueness of the product, the quality of the offered product, and the price competition.

The dimension of taking advantage of opportunities is the part of the entrepreneurial competency that is destined for business actors to have a careful instinct in viewing various opportunities and exploit these opportunities concretely to gain recognition and development to realize competitive advantage. Utilizing the opportunity is the principal for every business actor such as MSME to always search, determine, and exploit the opportunities available to be able to develop seaweed product business by continuously expanding the development in realizing competitive advantage based on the uniqueness of the product, the quality of the offered product, and the price competition.

The dimension of building relationships that according to the assessment of the respondents is still weak is the part of the entrepreneurial competency that should be owned by business actors such as MSMEs in finding various relationships to be invited to cooperate in developing and expanding the partnership network to support the strengthening of business actors to be able to have competitive advantage. Building relationships means creating partnerships with other business actors working in the same field to develop and to promote business in order to become a competitive business leader to introduce the uniqueness of its products, to guarantee product quality, and to develop a competitive pricing policy.

The dimension of learning is the part of the entrepreneurial competency that must be had by every business actor to always look for various learning resources, then participate in the learning process, able to evaluate the achievement of a learning that has been occupied by business actors, which causes the business actor able to realize competitive advantage. The learning process of entrepreneurs in the field of entrepreneurship requires that business actors have experience, follow the existing development of skills from the training that followed, in order to lead and able to develop their business in accordance with the competitive advantage that must be actualized. The form of learning process requires business actors able to create work standards in order to have competitive advantage by constantly developing product uniqueness, product quality and competitive pricing in the process of trying as in the field of MSMEs of seaweed processing.

The dimension of personal ability is the part of the entrepreneurial competency in which every business actor is required to have a host to never give up in running the business, the knowledge of identifying opportunities and threats, strengths and weaknesses, as well as the ability to motivate themselves and others so that with the provision of these personal capabilities, business actors, such as MSMEs, are able to increase the competitive 
advantage with the same business actors. On this basis, it is necessary to continuously improve and enhance the ability of business actors that will be developed into a professional capability in the business field in order to increase competitive advantage.

Entrepreneurial competency is a capability had by business actors in running their business in accordance with their potential. The competence of business actors of MSMEs is seen from their ability to build concepts, take advantage of opportunities, build relationships, have potential learning, and have personal skills in striving to realize competitive advantage.

The reason for entrepreneurial competency has a positive and significant impact on competitive advantage because the success of MSMEs is determined by the ability of business actors in expanding their potential in concept, opportunity, customer relationship, learning activity, and personality ability shown to be very supportive for business actors to enhance competitive advantage in creating unique product ideas and concepts to market, able to exploit opportunities according to ability, cost and maintain good relationships with all parties in business, and also have the advantage to maintain competitive prices among business actors of MSMEs engaged in the same field.

Therefore, entrepreneurial competency has a positive and significant effect because every business actors seeks to develop a clear business competence concept, always strives to exploit business opportunities with various alternative methods, always builds and creates mutually beneficial partnership relationship, always willing to gain experience through learning process, and always improves the personal ability in facing the challenges and business dynamics that they do. This entrepreneurial competency guides the MSMEs business actors to always increase the competitive advantage on the processing of seaweed.

\section{CONCLUSION}

Based on the formulation of the problems explained and supported from theoretical and empirical studies, the research results are concluded as follows:

Entrepreneurial competency positively and significantly affects competitive advantage. Building concepts, taking advantage of opportunities, building learning relationships and personnel capabilities have been run as entrepreneurial competency in increasing competitive advantage. The better the entrepreneurial competence of an entrepreneur, the more increasing the competitive advantage will be.

Entrepreneurial competency has a direct positive and insignificant effect on marketing performance. The existing entrepreneurial competence is less supportive in realizing the achievement of marketing performance. It is because the high entrepreneurial competency that an entrepreneur possesses will drive to increase marketing performance.

\section{REFERENCES}

1. Ahmad, N. H., Halim, H. A., \& Zainal, S. R. M. (2010). Is Entrepreneurial Competency The Silver Bullet for SME Success in a Developing Nation. International Business Management, 4(2), 67-75.

2. Ainuddin, R. A., Beamish, P. W., Hulland, J. S., \& Rouse, M. J. (2007). Resource Attributes and Firm Performance in International Joint Ventures. Journal of World Business, 42(1), 47-60.

3. Arbuckle, James L, 1997, Amos 7.0 User's Guide. Chicago, IL: SPSS Inc.

4. Barney, J. (1991). Firm resources and sustained competitive advantage. Journal of management, 17(1), 99-120.

5. Barney, Jay B. (2007). Gaining and Sustaining Competitive Advantage. PearsonEducation Inc., Upper Saddle River, New Jersey.

6. Bird, B. (1995). Towards a Theory of Entrepreneurial Competency. Advances in Entrepreneurship, Firm Emergence and Growth, 2(1), 51-72.

7. Biro Pusat Statistik (BPS). (2015). Kontribusi UKM Indonesia. Jakarta 
8. Day, G. S., \& Wensley, R. (1988). Assessing advantage: a framework for diagnosing competitive superiority. The Journal of Marketing, 1-20.

9. Ferdinand, Augusty. (2000). "Manajemen Pemasaran: Sebuah Pendekatan Strategy". Research Paper Series. No.01 Program Magister Manajemen Universitas Diponegoro

10. Hasan, I. (2015). Penguatan Kompetensi Kewirausahaan dan Daya Saing UKM Komoditi Unggulan Ekspor di Provinsi Aceh. INFOKOP, 19(1).

11. Jauch, Lawrence. R dan Glueck, William. (1998). Manajemen Strategis dan Kebijakan Perusahaan. Terjemahan Murad dan Henry Sitanggang. Penerbit Erlangga. Jakarta.

12. Kiggundu, M. N. (2002). Entrepreneurs and Entrepreneurship in Africa: What is known and what needs to be done. Journal of developmental entrepreneurship, 7(3), 239

13. Man, T. W., Lau, T., \& Chan, K. F. (2002). The Competitiveness of Small and Medium Enterprises: A conceptualization With Focus on Entrepreneurial competencies. Journal of business venturing, 17(2), 123-142.

14. Porter, M. E., \& Van der Linde, C. (1995). Toward a new conception of the environmentcompetitiveness relationship. The journal of economic perspectives, 9(4), 97-118. 